Article

\title{
Development of a Short-Cut Combined Magnetic Coagulation-Sequence Batch Membrane Bioreactor for Swine Wastewater Treatment
}

\author{
Yanlin Chen ${ }^{1,2,3}$, Qianwen Sui ${ }^{1,2}$, Dawei Yu ${ }^{1,2} \mathbb{D}$, Libing Zheng ${ }^{1,2}$, Meixue Chen ${ }^{1,2}$, Tharindu Ritigala ${ }^{1,2,3}$ and \\ Yuansong Wei ${ }^{1,2,3,4, *(D)}$
}

check for updates

Citation: Chen, Y.; Sui, Q.; Yu, D.; Zheng, L.; Chen, M.; Ritigala, T.; Wei, Y. Development of a Short-Cut Combined Magnetic

Coagulation-Sequence Batch Membrane Bioreactor for Swine Wastewater Treatment. Membranes 2021, 11, 83. https://doi.org/ 10.3390/membranes11020083

Academic Editors: Geoffroy Lesage and Amine Charfi

Received: 6 December 2020

Accepted: 20 January 2021

Published: 23 January 2021

Publisher's Note: MDPI stays neutral with regard to jurisdictional claims in published maps and institutional affiliations.

Copyright: (C) 2021 by the authors. Licensee MDPI, Basel, Switzerland. This article is an open access article distributed under the terms and conditions of the Creative Commons Attribution (CC BY) license (https:/ / creativecommons.org/licenses/by/ $4.0 /)$.
1 State Key Joint Laboratory of Environment Simulation and Pollution Control, Research Center for Eco-Environmental Sciences, Chinese Academy of Sciences, Beijing 100085, China; ylchen_st@rcees.ac.cn (Y.C.); qwsui@rcees.ac.cn (Q.S.); dwyu@rcees.ac.cn (D.Y.); lbzheng@rcees.ac.cn (L.Z.); mxchen@rcees.ac.cn (M.C.); tharindu_st@rcees.ac.cn (T.R.)

2 Laboratory of Water Pollution Control Technology, Research Center for Eco-Environmental Sciences, Chinese Academy of Sciences, Beijing 100085, China

3 University of Chinese Academy of Sciences, Beijing 100049, China

4 Institute of Energy, Jiangxi Academy of Sciences, Nanchang 330029, China

* Correspondence: yswei@rcees.ac.cn

\begin{abstract}
A high concentration of suspended solids (SS) in swine wastewater reduces the efficiency of the biological treatment process. The current study developed a short-cut combined magnetic coagulation (MC)-sequence batch membrane bioreactor (SMBR) process to treat swine wastewater. Compared with the single SMBR process, the combined process successfully achieved similarly high removal efficiencies of chemical oxygen demand (COD), total nitrogen (TN), ammonium nitrogen $\left(\mathrm{NH}_{4}^{+}-\mathrm{N}\right)$, and total phosphorous (TP) of $96.0 \%, 97.6 \%, 99.0 \%$, and $69.1 \%$, respectively, at dosages of $0.5 \mathrm{~g} / \mathrm{L}$ of poly aluminium chloride (PAC), $2 \mathrm{mg} / \mathrm{L}$ of polyacrylamide (PAM), and $1 \mathrm{~g} / \mathrm{L}$ of magnetic seeds in Stage II, and concentrations of TN, COD, and $\mathrm{NH}_{4}^{+}-\mathrm{N}$ in effluent can meet the discharge standards for pollutants for livestock and poultry breeding (GB18596-2001, China). The nitrogen removal loading (NRL) was increased from 0.21 to $0.28 \mathrm{~kg} /\left(\mathrm{m}^{3} \cdot \mathrm{d}\right.$ ), and the hydraulic retention time (HRT) was shortened from 5.0 days to 4.3 days. High-throughput sequencing analysis was carried out to investigate microbial community evolution, and the results showed that the relative abundance of ammonia-oxidizing bacteria (AOB) in the SMBR increased from $0.1 \%$ without pre-treatment to $1.78 \%$ with the pre-treatment of MC.
\end{abstract}

Keywords: magnetic coagulation; SMBR; nitritation-denitritation; TP; swine wastewater

\section{Introduction}

According to the Bulletin of the Second National Census of Pollution Sources in China, announced in June 2020, the livestock industry is the main source of water pollutants discharged in the agricultural industry, i.e., chemical oxygen demand (COD), $\mathrm{NH}_{4}^{+}-\mathrm{N}$, total nitrogen (TN), and total phosphorous (TP) accounted for 93.76\%, 51.30\%, 42.14\%, and $56.46 \%$, respectively, in 2017 [1]. It was reported that the amount of swine wastewater produced in China increased by approximately 0.16 billion tons every year [2], and swine wastewater treatment is of great concern due to the high concentration of organic matter, nitrogen, phosphorus, suspended solids, and other toxic compounds [3-5], such as COD (5512-55,000 mg/L), $\mathrm{NH}_{4}^{+}-\mathrm{N}$ (110-1650 mg/L), TN (200-2055 mg/L), TP (100-620 mg/L), and suspended solids (SS) (1117-4837 mg/L) [6-8].

Currently, conventional wastewater treatment processes are widely used in the swine wastewater treatment industry, mostly consisting of physical, chemical, and biological treatment processes. These biological treatment processes are combined with an anaerobic digestion process [9] to reduce the concentration of $\mathrm{COD}$, and anoxic/oxic $(\mathrm{A} / \mathrm{O})$ processes 
to remove further dissolved COD and nitrogen in swine wastewater [10]. However, the conventional biological treatment processes are lengthy and require a long hydraulic retention time (HRT), ranging from 10 to $60 \mathrm{~d}$ [11] and require a large bioreactor and more land area. Therefore, the high capital, operation, and maintenance costs are considered the main obstacles for treating conventional swine wastewater treatment processes and its spreading applications [12]. A sequence batch membrane bioreactor (SMBR)-based nitritation-denitritation process was developed by Sui et al. to treat swine wastewater, and it was reported that the removal efficiencies of $\mathrm{COD}, \mathrm{NH}_{4}^{+}-\mathrm{N}$, and $\mathrm{TN}$ were $95 \%, 99 \%$, and $93 \%$, respectively, and the effluent water quality met the pollutant discharge standard for livestock and poultry breeding (GB18596-2001, China) [13]. The high concentration of SS causes inhibition of microbial communities in subsequent biological treatment and leads to clogging in bioreactors and disintegration of the activated sludge and, finally, low removal efficiency [3,14-16]. Therefore, there is a necessity to develop a cost-effective pre-treatment process to remove the SS and improve the performance of subsequent biological treatment processes in swine wastewater treatment.

Coagulation-flocculation is widely used as a pre-treatment process to treat domestic and industrial wastewater, and poly aluminium chloride (PAC)-based coagulation is considered as the most popular coagulation method. However, conventional coagulation is considered a time-consuming process which requires approximately more than $30 \mathrm{~min}$ for settling. Additionally, low floc strength, poor density, and loose structure are other drawbacks in conventional coagulation for treating swine wastewater. The magnetic coagulation (MC) process drastically accelerated the sedimentation rate and shortened the HRT by up to $2-5$ min $[17,18]$, and reduced the sludge volume by $30 \%$ compared with conventional coagulation $[17,19]$. The MC process also shows advantages such as better removal performance, denser sludge, smaller required land area, and recovery of magnetic seeds [20]. In the conventional coagulation process, insoluble metal phosphate precipitates are formed by hydrolysis of the coagulant, and the precipitates are removed by settling. However, compared with conventional coagulation, magnetic coagulation produces turbulent force after adding magnetic powder, which increases the effective collision between the particles. Magnetic adsorption and aggregation make the magnetic coagulation process more effective than conventional coagulation, improving the structure and strength of the flocs, thereby increasing the efficiency of solid-liquid separation and achieving sludge reduction [19] and removing suspended particles and colloidal substances in wastewater, thus reducing the chemical agent consumption and improving the removal efficiency [21]. As a cost-effective pre-treatment process, magnetic coagulation is being paid more and more attention, and it has been widely applied in high-strength wastewater treatment with high removal efficiencies of COD and TP $[19,22]$ due to its effective removal of SS, $\mathrm{COD}$, phosphate, and TP, which could mitigate the organic loading rate and improve the treatment performance for subsequent biological wastewater treatment processes [22,23].

Though the SMBR showed excellent performances for removing $\mathrm{COD}, \mathrm{NH}_{4}^{+}-\mathrm{N}$, and TN [13], the high SS concentration in the swine wastewater may reduce the treatment loading of the SMBR and have impacts on membrane fouling. The SMBR did not include phosphorus removal, and it cannot meet the increasing demands for nutrient removal in the future due to increasingly stringent regulations in China. Therefore, the purpose of this research is to develop a short-cut process by combining MC and an SMBR to meet the discharge requirements of $\mathrm{COD}$ and ammonia without carbon addition in treating swine wastewater, and then remove as much phosphorus as possible. In this study, the coupling of swine wastewater pre-treatment under different $\mathrm{MC}$ conditions and the continuous operation of the subsequent SMBR process are investigated by lab-scale experiments. The microbial community evolution in the SMBR, as well as the bacteria related to nitrogen transformation, are analyzed by utilizing a high-throughput sequencing analysis. 


\section{Materials and Methods}

\subsection{Setup and Experimental Design of the Combined Process}

The combined MC-SMBR process setup consisted of an MC unit and an SMBR unit, as shown in Figure 1. The MC unit was made of cylinder plexiglass with an effective volume of $4 \mathrm{~L}$ (diameter $200 \mathrm{~mm} \times$ height $190 \mathrm{~mm}$ ), and a mechanical stirring device was installed in the middle of the reactor. The SMBR with an effective volume of $30 \mathrm{~L}$ (L $260 \mathrm{~mm} \times \mathrm{W} 260 \mathrm{~mm} \times \mathrm{H} 450 \mathrm{~mm}$ ) was equipped with an air compressor (Aerator I) for oxygen supply by aeration, and a mechanical stirrer was placed in the center of the reactor for mixing during the feeding and reaction phases. A polyvinylidene fluoride (PVDF) flat membrane module (SINAP Membrane Tech Co, Shanghai, China) with a pore size of $0.1 \mathrm{~mm}$ and a surface area of $0.5 \mathrm{~m}^{2}$ fixed in a frame was installed in the back of the reactor [13]. In addition, the perforated pipe with a pore size of $5 \mathrm{~mm}$ (Aerator II) and a rate of $5 \mathrm{~L} / \mathrm{min}$ was set under the membrane module for membrane flushing to control membrane fouling. The operational temperature was held during the experiment between $25^{\circ} \mathrm{C}$ and $28^{\circ} \mathrm{C}$ using a water bath.

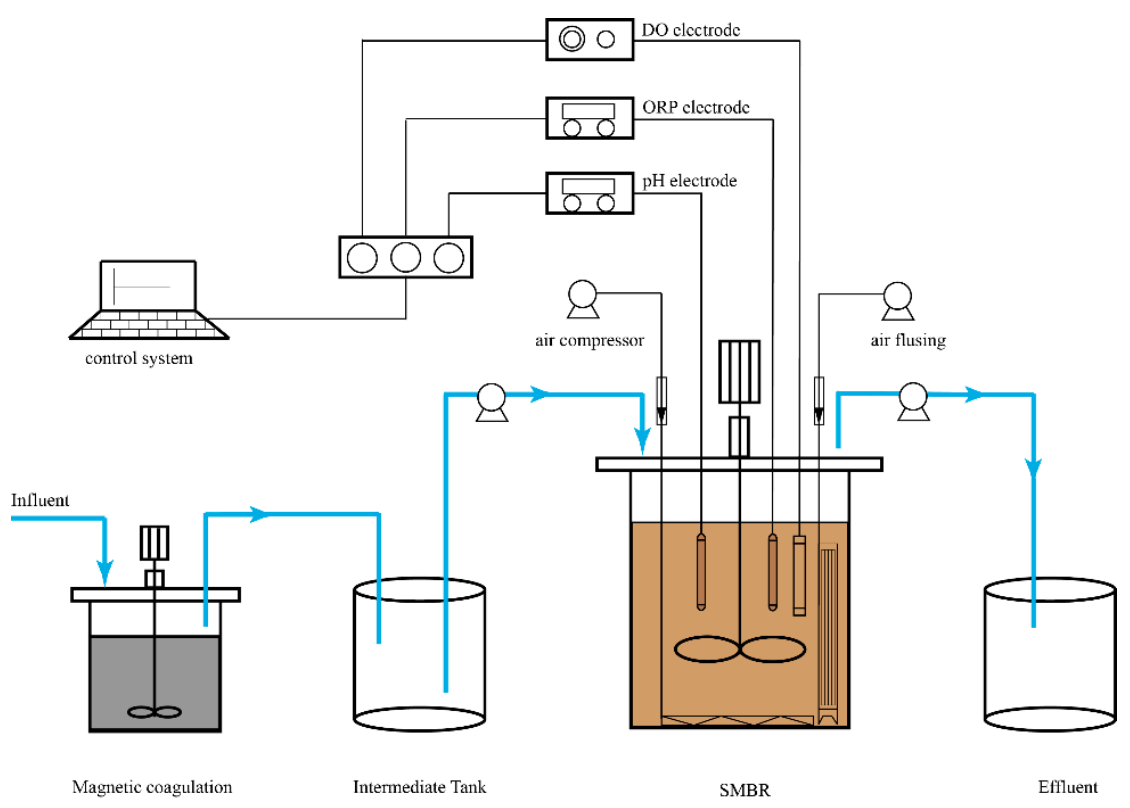

Figure 1. Setup of the combined magnetic coagulation and the sequence batch membrane bioreactor (SMBR).

\subsection{Raw Swine Wastewater and Operational Parameters of Magnetic Coagulation}

The raw swine wastewater used in this study was collected from a confined swine farm with a holding capacity of 10,000 heads and stored in a cooler room at $4-6{ }^{\circ} \mathrm{C}$. The characteristics of the raw swine wastewater are listed in Table 1. PAC was used as a coagulant, the flocculant was polyacrylamide (PAM) in the experiments, and magnetic powder was used as an additive to accelerate the settling rate. PAC, PAM, and magnetic seeds were purchased from the commercial market as industrial-grade reagents. 
Table 1. Characteristics of influent swine wastewater at different stages (mg/L).

\begin{tabular}{|c|c|c|c|c|c|c|c|c|}
\hline Stage & COD & $\mathrm{NH}_{4}{ }^{+}-\mathrm{N}$ & TN & $\mathrm{PO}_{3}^{--} \mathrm{P}$ & TP & SS & $\mathrm{pH}$ & $\mathrm{T}\left({ }^{\circ} \mathrm{C}\right)$ \\
\hline I & $9227.2 \pm 1012.8$ & $943.4 \pm 162.5$ & $1097.0 \pm 184.5$ & $114.3 \pm 8.6$ & $132.4 \pm 5.8$ & $2348.33 \pm 268.3$ & $8.1-8.5$ & $25-27$ \\
\hline II & $10,141.3 \pm 1292.3$ & $1245.7 \pm 271.2$ & $1514.9 \pm 126.4$ & $140.2 \pm 15.2$ & $159.1 \pm 14.7$ & $2263.7 \pm 248.4$ & $8.0-8.5$ & $25-27$ \\
\hline III & $11,507.3 \pm 1817.4$ & $1031.3 \pm 181.1$ & $1201.5 \pm 145.7$ & $134.4 \pm 13.9$ & $152.4 \pm 12.4$ & $2375 \pm 196.3$ & $8.1-8.4$ & $25-28$ \\
\hline
\end{tabular}

The MC tests were performed batch-wise using a coagulation device, as shown in Figure 1. The steps of the experiments were as follows: (1) at room temperature, $4 \mathrm{~L}$ of swine wastewater were added to the MC device; (2) the liquid was rapidly stirred at $300 \mathrm{r} / \mathrm{min}$ for $60 \mathrm{~s}$ for coagulation, and PAC and magnetic powder (particle size $13 \mu \mathrm{m}$ ) were added immediately after the fast stirring; (3) the mixture was then slowly stirred at $70 \mathrm{r} / \mathrm{min}$ for $110 \mathrm{~s}$ for flocculation, and polyacrylamide (PAM) was added immediately after this slow stirring; (4) the mixture was allowed to settle for $20 \mathrm{~min}$. After the settling, the supernatant samples were collected in a storage tank for the subsequent SMBR treatment.

To explore the effects of $\mathrm{MC}$ on the biological nitrogen removal performance of the SMBR, the experiment was divided into three periods according to the different conditions of the MC, as follows:

Stage I (D1-91): As the control, the swine wastewater was directly fed into the SMBR reactor without MC pre-treatment.

Stage II (D92-135): The swine wastewater was fed into the SMBR reactor after the MC pre-treatment. Dosages of $0.5 \mathrm{~g} / \mathrm{L}$ of PAC, $2 \mathrm{mg} / \mathrm{L}$ of PAM, and $1 \mathrm{~g} / \mathrm{L}$ of magnetic seeds were used during MC in this stage.

Stage III (D136-171): The swine wastewater was fed into the SMBR reactor after an enhanced MC pre-treatment process to improve phosphorus removal. The enhanced dosages were $1.5 \mathrm{~g} / \mathrm{L}$ of PAC, $2 \mathrm{mg} / \mathrm{L}$ of PAM, and $1 \mathrm{~g} / \mathrm{L}$ of magnetic seeds.

\subsection{Operation of the $S M B R$}

According to Sui et al., real-time control logic was applied to the SMBR [13]. At the beginning of each cycle, $1 \mathrm{~L}$ of wastewater was pumped into the reactor when it was in the anoxic phase, then the air pump was started to supply oxygen for the oxic phase. The duration of the anoxic and oxic phases was determined by real-time control through online sensors of the $\mathrm{pH}$, Oxidation-Reduction Potential (ORP), and Dissolved Oxygen (DO), indicating the completion of ammonia oxidation and denitrification. Lastly, the membrane efflux pump was started, and the effluent discharge time was set according to the membrane flux and pump power.

The external carbon source (sodium acetate, $10^{4} \mathrm{mg} / \mathrm{L}$ ) dosing pump in the SMBR reactor was only used in Stage III and not in Stage I and Stage II. The HRT of the SMBR ranged from $4.3 \mathrm{~d}$ to $5 \mathrm{~d}$, sludge retention time (SRT) was 15 to $20 \mathrm{~d}$, and the exchange ratio was set at $1 / 30$. The mixed liquor suspended solids (MLSS) in the reactor varied in the range of $6-10 \mathrm{~g} / \mathrm{L}$, and the ratio of mixed liquor volatile suspended solids (MLVSS)/MLSS was $0.58-0.77$. The loading rates of COD and TN were at $0.2-0.4 \mathrm{~kg} /(\mathrm{kg} \cdot \mathrm{VSS} \mathrm{d})$ and $0.049-0.67 \mathrm{~kg} /(\mathrm{kg} \cdot \mathrm{VSS} \cdot \mathrm{d})$, respectively.

\subsection{Analysis Methods}

The MLSS and MLVSS were determined by the weight method. The concentrations of $\mathrm{COD}, \mathrm{NH}_{4}^{+}-\mathrm{N}, \mathrm{NO}_{2}^{-}-\mathrm{N}, \mathrm{NO}_{3}^{-}-\mathrm{N} ; \mathrm{TN}, \mathrm{PO}_{4}{ }^{3-}-\mathrm{P}, \mathrm{TP}$, and $\mathrm{SS}$ were analyzed using the standard methods (APHA, 2005).

Samples of the activated sludge in the SMBR at Stage I (d77, d85, d91), Stage II (d115, d127, d135), and Stage III (d155, d163, d171) were collected for microbial community analysis. DNA extraction was done, as described by Sui et al. [24].

A beaker with a working volume of $1 \mathrm{~L}$ was used for the aerobic batch test to evaluate the activities of ammonia-oxidizing bacteria (AOB) and nitrite-oxidizing bacteria (NOB) [25]. The beaker was equipped with a magnetic stirrer, diffuser, and online sensors for monitoring DO, pH, and temperature (Multi 3420, WTW, Munich, Germany). A total of 
$500 \mathrm{~mL}$ of the mixed liquor was collected from the SMBR with a dosage of approximately $40 \mathrm{mg} \mathrm{N} / \mathrm{L}$ of ammonium for the aerobic batch tests, the temperature was controlled at $25 \pm 2{ }^{\circ} \mathrm{C}$, and DO was maintained above $4.0 \mathrm{mg} / \mathrm{L}$. Water samples were collected every $15 \mathrm{~min}$ and filtered through a $0.45 \mu \mathrm{m}$ micropore poly-ethersulfone (PES) membrane to test ammonium, nitrite, and nitrate concentrations. Based on these data, the activities of $\mathrm{AOB}$ and NOB were determined by using Equations (S1) and (S2).

\subsection{Data Analysis}

Canoco 5.0 (Microcomputer Power, New York, USA) was used to conduct the principal component analysis (PCA) of the microbial community. The figures were plotted by Origin 9.0 (OriginLab, Northampton, MA, USA). A heatmap was made by using HemI (http:/ /hemi.biocuckoo.org/). The nitrite accumulation ratio (NAR) was calculated using the following equation:

$$
\mathrm{NAR}=\frac{\left[\mathrm{NO}_{2}^{-}-\mathrm{N}\right]_{\mathrm{eff}}}{\left[\mathrm{NO}_{2}^{-}-\mathrm{N}\right]_{\mathrm{eff}}+\left[\mathrm{NO}_{3}^{-}-\mathrm{N}\right]_{\mathrm{eff}}} \times 100 \%
$$

where $\left[\mathrm{NO}_{2}^{-}-\mathrm{N}\right]_{\text {eff }}(\mathrm{mg} / \mathrm{L})$ and $\left[\mathrm{NO}_{3}^{-}-\mathrm{N}\right]_{\text {eff }}(\mathrm{mg} / \mathrm{L})$ are the effluent concentrations of nitrite and nitrate, respectively.

\section{Results and Discussion}

3.1. Treatment Performance of the Combined MC-SMBR Process

\subsubsection{Pre-Treatment of MC}

The results of the MC process are shown in Figure 2 and Table S1. The concentrations of $\mathrm{COD}, \mathrm{NH}_{4}^{+}-\mathrm{N}, \mathrm{PO}_{4}{ }^{3-}-\mathrm{P}, \mathrm{TP}$, and SS of influent during Stage II decreased from 10141.3, $1245.7,140.2,159.1$, and $2263.7 \mathrm{mg} / \mathrm{L}$ to $7693.8,1212.7,43.4,52.2$, and $1146.4 \mathrm{mg} / \mathrm{L}$, respectively, and the corresponding removal efficiencies are $24.1 \%, 2.6 \%, 68.8 \%, 67.1 \%$, and $49.4 \%$, respectively. The MC exhibited better removal of $\mathrm{PO}_{4}{ }^{3-}-\mathrm{P}, \mathrm{TP}$, and SS than COD and $\mathrm{NH}_{4}^{+}-$ $\mathrm{N}$. The $\mathrm{C} / \mathrm{N}$ ratio of influent was decreased from 8.1 to 5.4 , which meets the minimum requirements of the $\mathrm{C} / \mathrm{N}$ ratio for nitrogen removal by the nitritation-denitritation process.

During Stage III, the concentrations of $\mathrm{COD}, \mathrm{NH}_{4}^{+}-\mathrm{N}, \mathrm{PO}_{4}{ }^{3-}-\mathrm{P}, \mathrm{TP}$, and SS decreased from 11507.3, 1031.3, 134.4, 152.4, and $2375 \mathrm{mg} / \mathrm{L}$ to $4936.3,962.5,30.5,35.8$, and 271.7 $\mathrm{mg} / \mathrm{L}$, respectively, and the corresponding removal efficiencies are $57.1 \%, 6.7 \%, 77.3 \%$, $76.5 \%$, and $88.6 \%$, respectively. The $\mathrm{C} / \mathrm{N}$ ratio of the influent was decreased from 11.2 to 4.1 , which means external carbon source dosing was needed in Stage III. 
VII/, Before magnetic coagulation $\quad X X X$ After magnetic coagulation $\star \star$ Removal efficiency
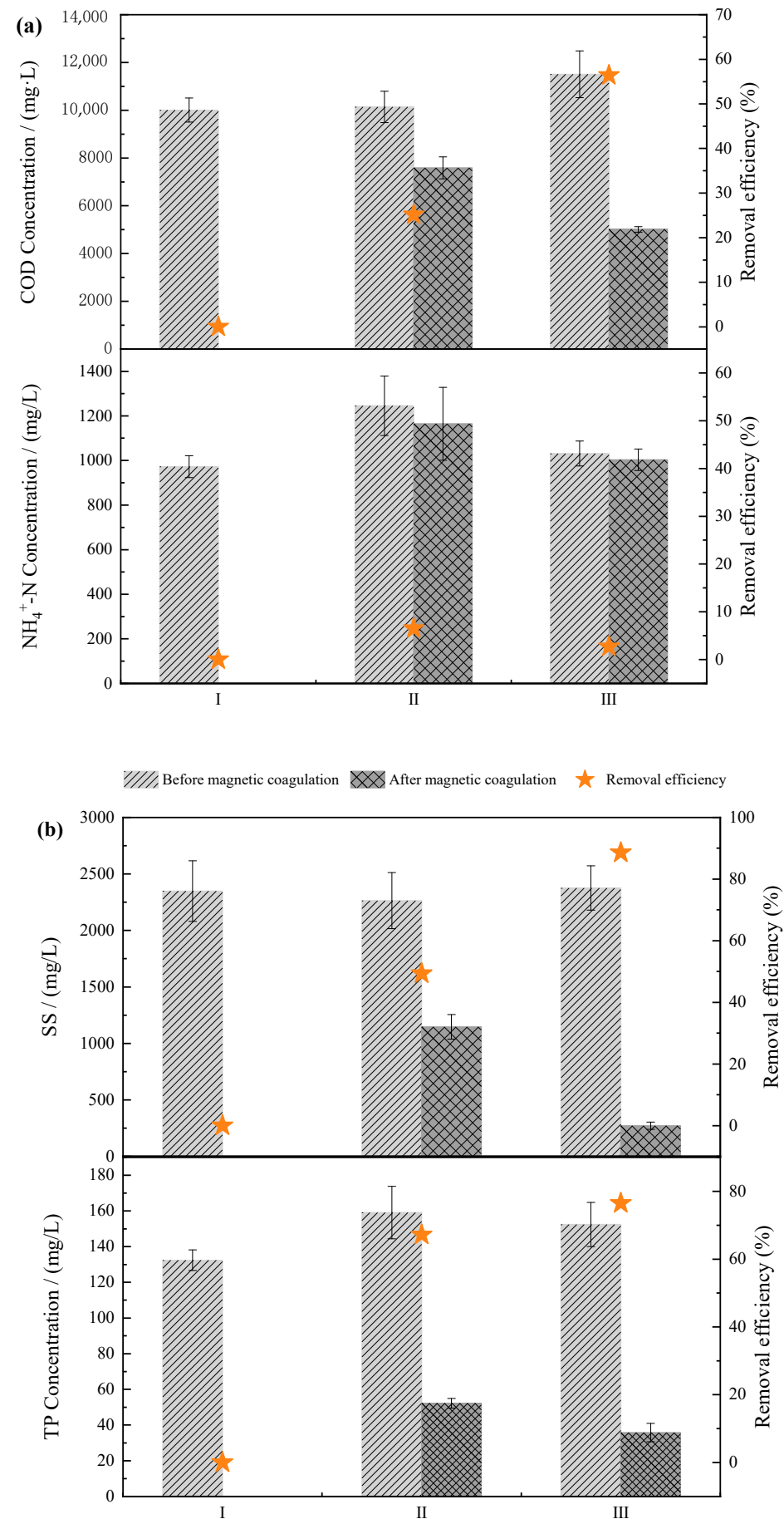

Figure 2. Performance of the magnetic coagulation pre-treatment of swine wastewater. (a) COD, $\mathrm{NH}_{4}^{+}$-N removal performance (b) SS, TP removal performance

The swine wastewater contains urine, feed residue, flushing water, residual feces, and wastewater produced by livestock and poultry breeding plants [26]. Urine is the primary source of ammonia nitrogen in swine wastewater, and the organic matter comes from residual feces. In the MC process, SS in the wastewater used the magnetic species as the core to form flocs (alum flowers), and flocs were settled with the gravitational force [23]. On the other hand, as an inorganic polymer, PAC could hydrolyze and polymerize to form various aluminum hydroxyl compounds. With a high positive charge and specific surface area, the aluminum hydroxyl compound has a good adsorption effect on impurities 
and colloidal substances. Simultaneously, it can effectively reduce the zeta potential of colloids and promote the occurrence of flocculation. $\mathrm{Al}^{3+}$ also reacts with phosphate ions to form $\mathrm{AlPO}_{4}$ to obtain better phosphorus removal efficiency [27]. The addition of magnetic powder is more effective for the adsorption of suspended particles and colloids in wastewater, leading to a better sedimentation performance and higher removal of TP in effluent [21]. The chemical precipitation method based on the MC process was more efficient than other available technologies, such as biological phosphorus removal [28], the adsorption method [29], and struvite crystallization [30] used for phosphorus removal from swine manure. Additionally, MC was not limited to temperature, organic matter, and $\mathrm{pH}$.

The MC method mainly removed the SS, organic matter, and TP from the swine wastewater and increased the corresponding removal along with increasing the PAC dosage. While ensuring the removal efficiency of pollutants, the MC method uses magnetic seeds as the core of the floc, promotes the close combination of flocs, improves the flocculation settling performance, and reduces sludge volume [31].

\subsubsection{Treatment Performance of the SMBR}

The overall performance of the SMBR is shown in Figure 3. In Stage I, swine wastewater without MC pre-treatment was fed into the SMBR. The average concentrations of $\mathrm{NH}_{4}^{+}$ $\mathrm{N}, \mathrm{TN}, \mathrm{COD}$, and TP (Table S2) in the influent were 943.4, 1097.0, 9227.2, and $132.4 \mathrm{mg} / \mathrm{L}$, respectively, and corresponding average effluent concentrations in the SMBR were 8.6, 38.0, 335.9, and $125.3 \mathrm{mg} / \mathrm{L}$, respectively, and the corresponding removal efficiencies of $\mathrm{NH}_{4}^{+}-\mathrm{N}, \mathrm{TN}, \mathrm{COD}$, and TP were $99.1 \%, 96.5 \%, 96.4 \%$, and $5.4 \%$, respectively. The average concentration of nitrite in the effluent reached $13.5 \mathrm{mg} / \mathrm{L}$, and the average NAR was 73.5\%. A previous study [13] showed that the hydrogen ions produced during the oxidation of ammonia nitrogen decreased the $\mathrm{pH}$ when the ammonia oxidation process was completed; thus, a characteristic "ammonia valley point" appears in the $\mathrm{pH}$ variation curve. The distinctive points of the $\mathrm{pH}$ change curve can be used to indicate the state of the ammonia oxidation process completion, thus realizing a nitritation-denitritation process to remove nitrogen in the wastewater [32].

In Stage II, with the MC pre-treatment, the average concentrations of $\mathrm{NH}_{4}^{+}-\mathrm{N}, \mathrm{TN}$, COD, and TP in the influent were 1212.7, 1422.7, 7693.8, and $52.2 \mathrm{mg} / \mathrm{L}$, respectively, and their average effluent concentrations in the SMBR were 12.4, 36.9, 401.6, and $49.2 \mathrm{mg} / \mathrm{L}$, with removal efficiencies of $99.0 \%, 97.4 \%, 94.8 \%$, and $5.7 \%$, respectively. The effluent COD concentration was higher in Stage II compared with Stage I, and the reason was that a high $\mathrm{NH}_{4}^{+}-\mathrm{N}$ concentration in the influent caused a high free ammonia concentration $(84 \mathrm{mg} / \mathrm{L})$; thus, the activity of COD-degrading heterotrophic bacteria was inhibited. Therefore, it reduced biodegradation due to the inhibition of heterotrophic bacteria and slightly increased the effluent COD concentration in the SMBR. On the other hand, TP removal efficiency was increased to $69.1 \%$ through the MC-SMBR process, which is much better than that in the SMBR process without MC pre-treatment.

Though the influent $\mathrm{C} / \mathrm{N}$ ratio of the SMBR was reduced from 8.7 to 5.4 due to the MC pre-treatment, the SMBR achieved a better performance of $97.4 \%$ of TN removal efficiency without dosing external carbon sources, and the NAR reached $78.1 \%$. The nitrogen removal loading rate increased from $0.21 \mathrm{~kg} \mathrm{~N} /\left(\mathrm{m}^{3} \cdot \mathrm{d}\right)$ (Stage I) to $0.28 \mathrm{~kg} \mathrm{~N} /\left(\mathrm{m}^{3} \cdot \mathrm{d}\right)$ (Stage II), with an increase of $33.33 \%$. On the one hand, the MC pre-treatment process effectively reduced the influent concentrations of SS, COD, phosphate, and TP. On the other hand, it decreased the HRT from $5.0 \mathrm{~d}$ (Stage I) to $4.7 \mathrm{~d}$ (Stage II) (Table S3). Furthermore, the MC promoted the specific activity of AOB (Figure S1) from 5.1 to $10.8 \mathrm{mgN} /(\mathrm{mg}$ MLSS.h), decreased the aeration time, and shortened the HRT of the SMBR by $14 \%$. The membrane permeability was increased from 0.23 to $0.28 \mathrm{~L} /\left(\mathrm{m}^{2} \cdot \mathrm{h} \mathrm{kPa}\right.$ ) (Figure S2), and Transmembrane Pressure (TMP) reduction rates were $0.53,0.47$, and $0.48 \mathrm{kPa} / \mathrm{d}$ in Stage I, Stage II, and Stage III, respectively. 

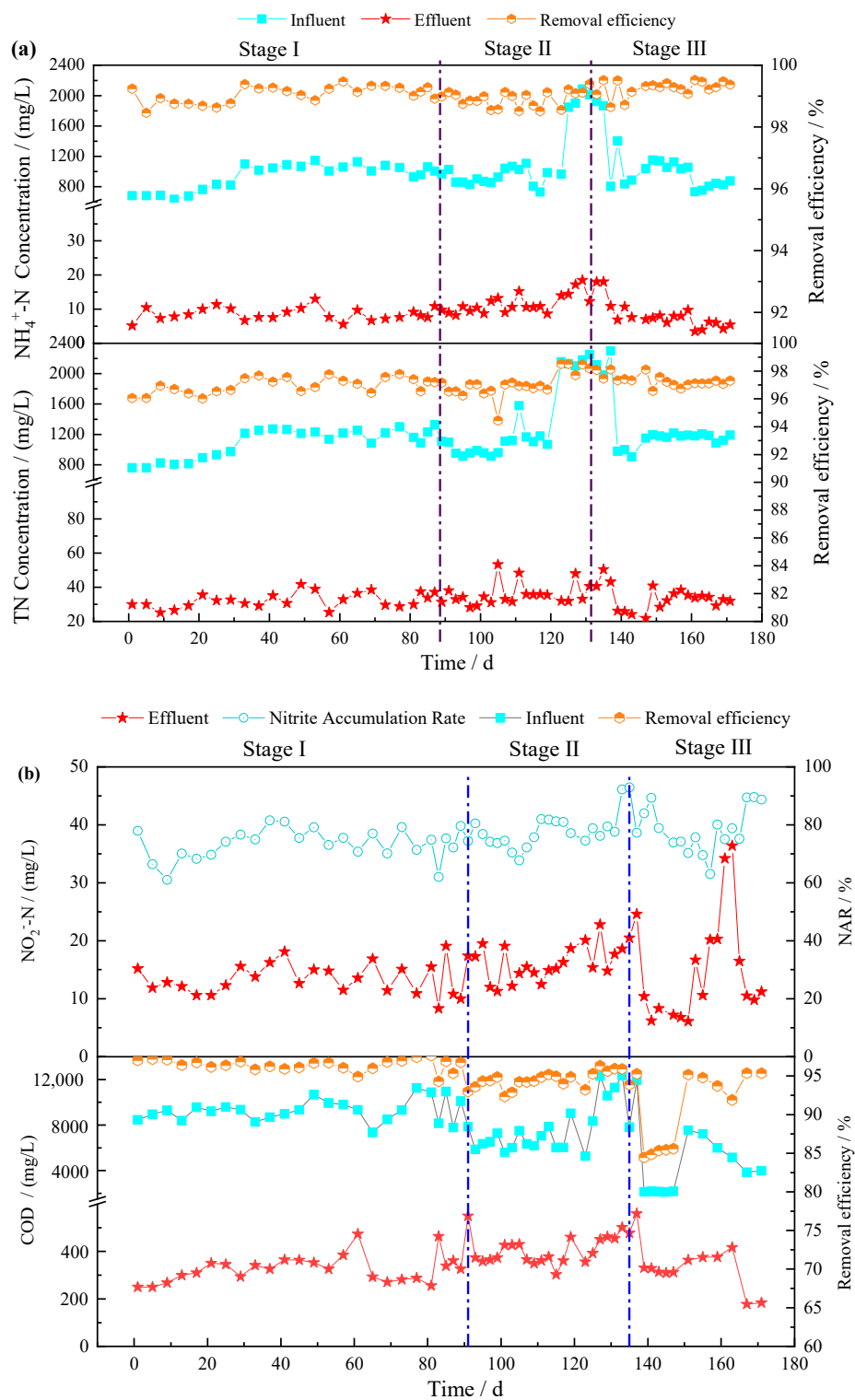

Figure 3. Performance of the SMBR treatment of swine wastewater. (a) $\mathrm{NH}_{4}^{+}-\mathrm{N}$ and TN removal (b) Nitrite accumulation and COD removal

In Stage III, the SMBR was operated with enhanced MC pre-treatment for removing more phosphorus. As shown in Figure 3, the average concentrations of $\mathrm{NH}_{4}^{+}-\mathrm{N}, \mathrm{TN}, \mathrm{COD}$, and TP in the influent were $962.5,1201.4,4936.3$, and $35.8 \mathrm{mg} / \mathrm{L}$, respectively, and their average effluent concentrations in the SMBR were $7.1,32.3,340.3$, and $33.2 \mathrm{mg} / \mathrm{L}$, with removal efficiencies of $99.3 \%, 97.3 \%, 93.1 \%$, and $7.2 \%$, respectively. The influent $\mathrm{C} / \mathrm{N}$ ratio of the SMBR further decreased to 4.1 after enhanced MC. An external carbon source (sodium acetate, $10^{4} \mathrm{mg} / \mathrm{L}$ ) was dosed into the SMBR to ensure the nitrogen removal efficiency of the SMBR during this stage. The average nitrogen removal loading was $0.27 \mathrm{~kg} \mathrm{~N} /\left(\mathrm{m}^{3} \cdot \mathrm{d}\right)$, and the HRT was reduced from $4.7 \mathrm{~d}$ to $4.3 \mathrm{~d}$, respectively, in Stage II and Stage III (Table S3). In addition, the nitrite concentration of the effluent averaged at $15.1 \mathrm{mg} / \mathrm{L}$ by increasing the contribution of nitrogen removal through a nitration-denitration process. At the end, the NAR reached $78.4 \%$.

In Stage III, the results indicated that with enhanced MC pre-treatment of swine wastewater, most of the $\mathrm{TP}, \mathrm{PO}_{4}{ }^{3-}-\mathrm{P}, \mathrm{SS}$, and solid organic matter were removed, leading to the residual becoming soluble biodegradable organic matter. Although organic matter is beneficial to improve the utilization efficiency of microorganisms, the influent 
$\mathrm{C} / \mathrm{N}$ ratio was too low to guarantee the sufficient required carbon for biological nitrogen removal; hence, an external carbon source was dosed to maintain a high total nitrogen removal efficiency.

Moreover, the combined MC-SMBR process demonstrated excellent removal efficiencies for $\mathrm{COD}, \mathrm{TN}, \mathrm{NH}_{4}^{+}-\mathrm{N}$, and $\mathrm{TP}$, with removal efficiencies of $97.0 \%, 97.3 \%, 99.3 \%$, and $78.2 \%$ in Stage III compared with the single SMBR process or other methods (Table S3) $[13,33]$. The effluent concentration of COD and $\mathrm{NH}_{4}^{+}-\mathrm{N}$ in the combined MC-SMBR process met the limits of $\mathrm{COD}$ and $\mathrm{NH}_{4}^{+}-\mathrm{N}$ in the Discharge Standard of Pollutants for Livestock and Poultry Breeding of China (GB18596-2001). Additionally, with the MC process, the nitrogen removal loading of the SMBR increased by $33 \%$ from 0.21 to $0.28 \mathrm{~kg} \mathrm{~N} /\left(\mathrm{m}^{3} \cdot \mathrm{d}\right)$, and the HRT was shortened by $14 \%$ from $5.0 \mathrm{~d}$ to $4.3 \mathrm{~d}$.

\subsubsection{Total Treatment Performance}

The short-cut combined MC-SMBR process in Stage II could effectively remove COD, $\mathrm{TN}$, and $\mathrm{NH}_{4}^{+}-\mathrm{N}$, with removal efficiencies of $96.0 \%, 97.6 \%$, and $99.0 \%$, respectively. The TP removal efficiency was $69.1 \%$, and it was far better than a single SMBR process. Considering the cost of external carbon sources and the required $\mathrm{C} / \mathrm{N}$ ratio for nitrogen removal in the SMBR, the dosages of PAC, PAM, and magnetic powder at $0.5 \mathrm{~g} / \mathrm{L}, 2 \mathrm{mg} / \mathrm{L}$, and $1 \mathrm{~g} / \mathrm{L}$, respectively, were more suitable for swine wastewater pre-treatment.

Compared with a single SMBR process, the combined MC-SMBR process can greatly enhance the solid-liquid separation efficiency and achieve a better removal performance of $\mathrm{COD}, \mathrm{NH}_{4}^{+}-\mathrm{N}, \mathrm{TN}$, and TP. As a pre-treatment, the MC process effectively decreased the organic load for the subsequent biological treatment and increased the load of biological nitrogen removal. Additionally, it improved AOB activity and the treatment efficiency of the SMBR. In technical and economic aspects, the combined MC-SMBR process could reduce the HRT of SMBR by $14 \%$, thus saving capital and operation and maintenance costs for swine wastewater treatment due to less aeration, a smaller reactor volume, and a smaller land area for biological treatment.

\subsection{Evolution of Nitrogen Compounds in Typical Cycles of the SMBR}

The variation of nitrogen compounds within a cycle at the different stages of the SMBR showed similar behavior, as shown in Figure 4. In Stage I, it can be seen that the SMBR was in an anoxic stage from 0 to $70 \mathrm{~min}$, and concentrations of $\mathrm{NO}_{2}^{-}-\mathrm{N}$ and $\mathrm{NO}_{3}^{-}-\mathrm{N}$ in the $\mathrm{SMBR}$ decreased sharply during the first $30 \mathrm{~min}$ of the cycle. The microorganisms used the organic matter in the influent were the electron donors to reduce $\mathrm{NO}_{2}^{-}-\mathrm{N}$ and $\mathrm{NO}_{3}^{-}-\mathrm{N}$ to nitrogen to achieve nitrogen removal. From the 70th minute, the $\mathrm{NH}_{4}^{+}-\mathrm{N}$ concentration decreased from $24.99 \mathrm{mg} / \mathrm{L}$ to $16.89 \mathrm{mg} / \mathrm{L}$, and $\mathrm{NO}_{2}^{-}-\mathrm{N}_{\text {and }} \mathrm{NO}_{3}^{-}-\mathrm{N}$ concentrations increased to $13.7 \mathrm{mg} / \mathrm{L}$ and $3.95 \mathrm{mg} / \mathrm{L}$, respectively. During this process, the DO gradually increased to approximately $3.8 \mathrm{mg} / \mathrm{L}$, and the $\mathrm{pH}$ gradually decreased from 8.19 to 7.89 . The "ammonia valley point" appeared at $210 \mathrm{~min}$, and delayed aeration enhanced the removal of organic matter in the swine wastewater. At the end of the cycle, the NAR was $77.6 \%$.

The real-time control strategy was used in the SMBR, in which the "ammonia valley point" on the $\mathrm{pH}$ curve was used to judge the end of the ammonia oxidation process to timely stop the aeration. Hence, the nitrification reaction stopped during the ammonia oxidation stage to reach a high NAR. When the $\mathrm{NH}_{4}^{+}-\mathrm{N}$ was completely degraded, the "ammonia valley point" appeared on the $\mathrm{pH}$ curve, and then $\mathrm{NO}_{2}^{-}-\mathrm{N}$ in the reactor was gradually transformed into $\mathrm{NO}_{3}^{-}-\mathrm{N}$. This phenomenon indicated that if the aeration was not stopped in time after the complete ammonia oxidation, the concentration of DO in the reactor might continue to increase, resulting in a decrease in the existing accumulation of $\mathrm{NO}_{2}^{-}-\mathrm{N}$. Therefore, the real-time control strategy was adopted to stop the aeration immediately after the degradation of $\mathrm{NH}_{4}^{+}-\mathrm{N}$ in each cycle to prevent further nitrite consumption. After using this real-time aeration strategy, AOB gradually became the dominant nitrifying bacteria, and the NAR gradually increased [34,35]. 


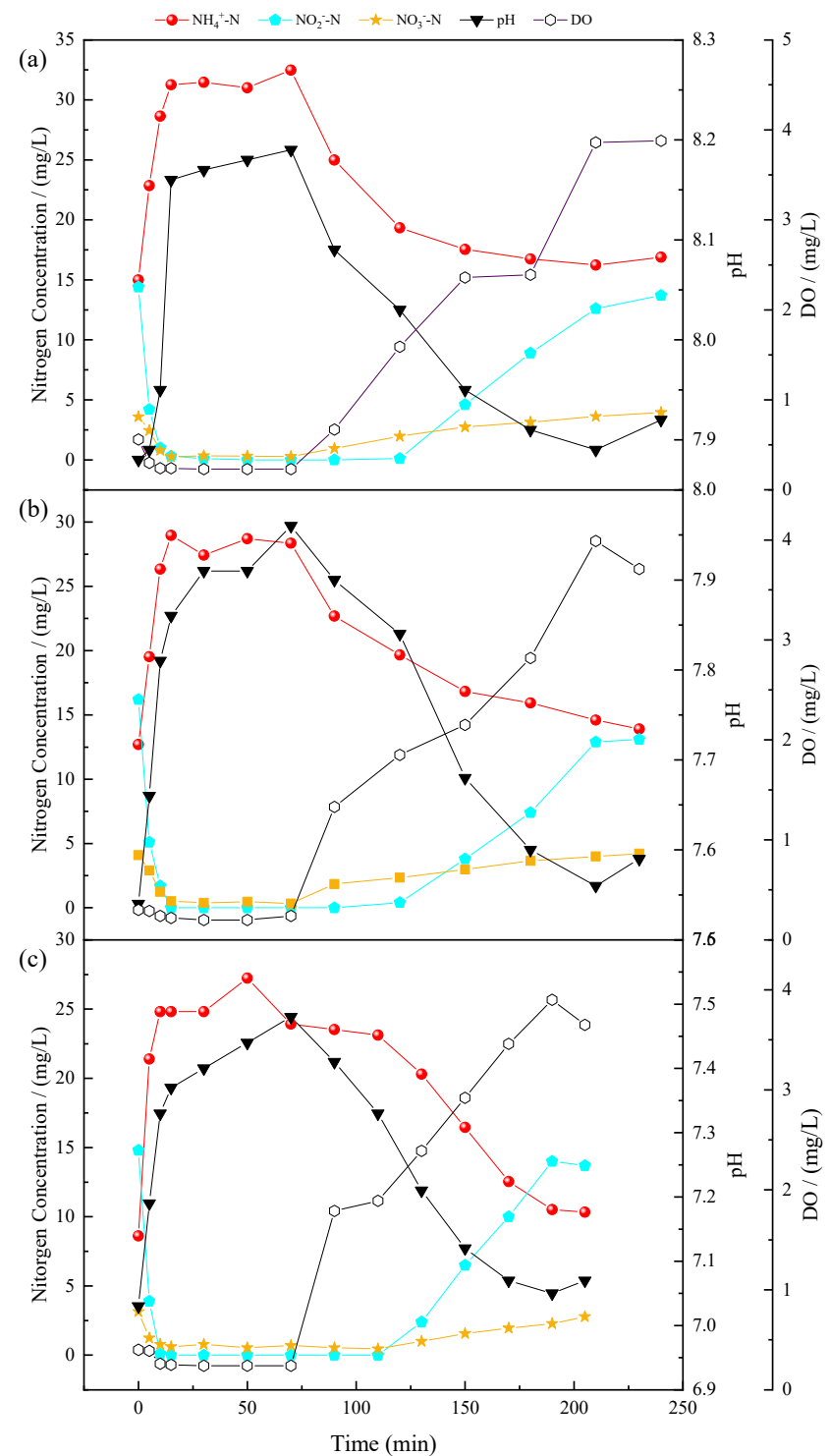

Figure 4. Evolution of nitrogen compounds during cycles in (a) Stage I, (b) Stage II, (c) Stage III.

The total cycle time of all stages was different, i.e., Stage I was $240 \mathrm{~min}$, Stage II was $230 \mathrm{~min}$, and Stage III was $205 \mathrm{~min}$. Therefore, the footprint of the SMBR was reduced by $4 \%$ and $14 \%$ in Stage II and Stage III, respectively, compared with that in Stage I. As shown in Figure S1, the AOB activities were 5.1, 8.1, and $10.8 \mathrm{mgN} /(\mathrm{mg}$ MLSS.h) in Stage I to Stage III, respectively, and the corresponding activity of NOB in Stage I was $1.95 \mathrm{mg} /(\mathrm{L} \cdot \mathrm{h})$, and no activity was detected during Stage II and Stage III. The time required for the ammonia oxidation process gradually decreased by $20 \%$, and the HRT of the SMBR decreased from $5.0 \mathrm{~d}$ to $4.3 \mathrm{~d}$ due to the increased $\mathrm{AOB}$ activity.

\subsection{Microbial Community Evolution in the SMBR}

The microbial communities of activated sludge in the SMBR during Stage I (d77, d85, d91), Stage II (d115, d127, d135), and Stage III (d155, d163, d171) were investigated using a high-throughput sequencing analysis. The relative taxonomic abundances of the microbial communities at a phylum level are shown in Figure 5a. The predominant phyla were Bacteroidetes (18.89-72.35\%), Proteobacteria (6.43-36.25\%), Patescibacteria (11.25-19.33\%), Firmicutes (4.21-16.40\%), Chloroflexi (0.54-14.72\%), and Actinobacteria (0.83-11.42\%). Compared with Stage I, the abundance of Bacteroidetes and Firmicutes increased during Stage II and Stage III, whereas the abundance of Proteobacteria, Chloroflexi, and Patescibacteria 
decreased. Bacteroidetes was the most abundant phylum and has the ability to metabolize the EPS generated by nitrifiers and secondary metabolites produced by biomass decay [36]. The Proteobacteria phylum was correlated with $\mathrm{NH}_{4}^{+}-\mathrm{N}$ removal and nitritation efficiency, including the genus Nitrosomonas, with high abundances in the SMBR $[37,38]$. Chloroflexi was involved in organic matter degradation, such as polysaccharides [39]. The main phylum level changed, as well as the stable performance of the SMBR, suggesting that there was a close association between the functional bacteria and the pollutant removal efficiency of the SMBR.
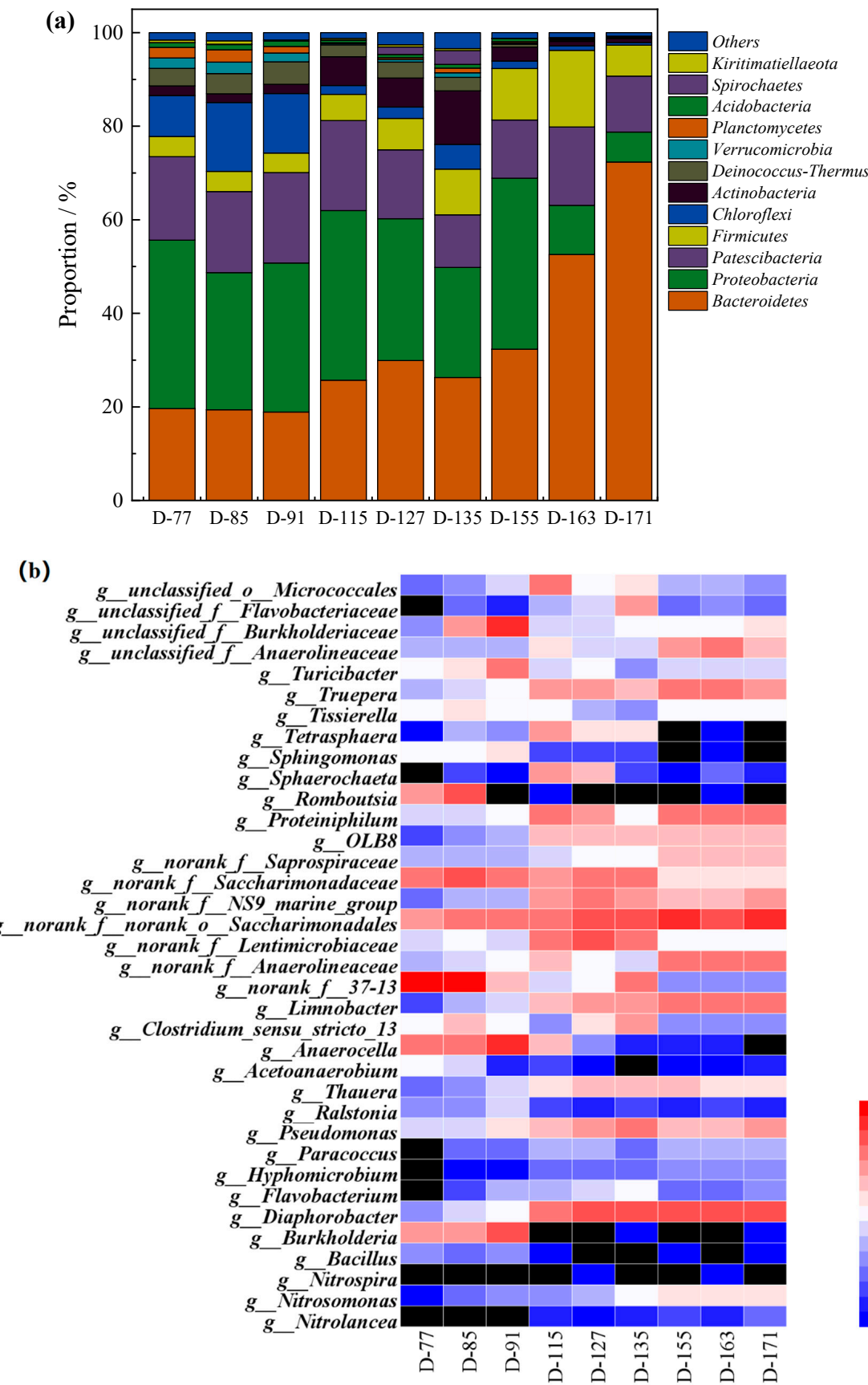

Figure 5. Cont. 


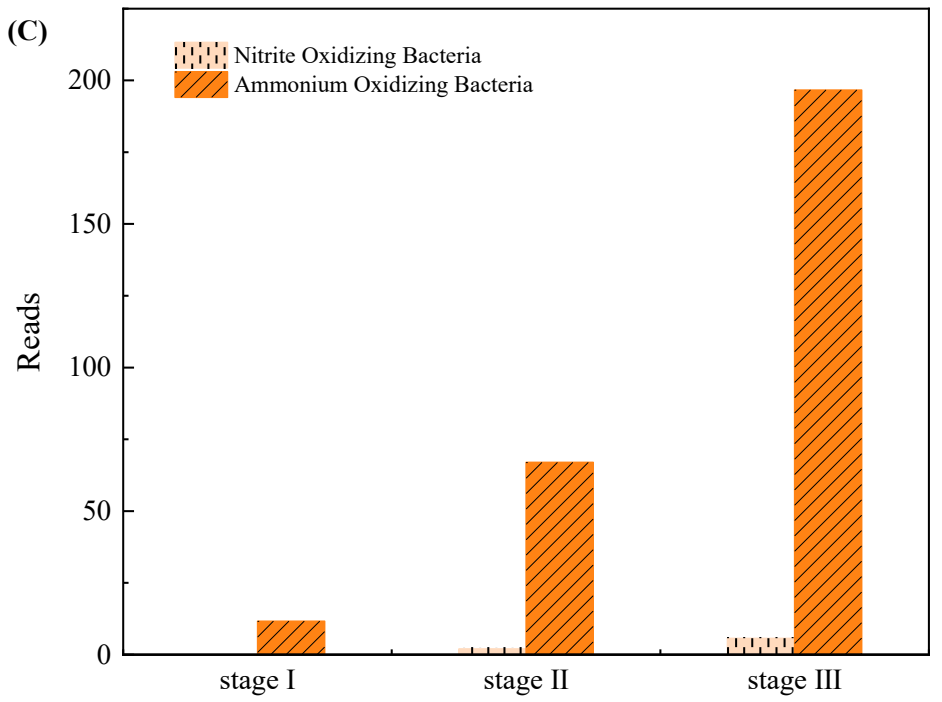

Figure 5. The distribution of bacterial communities in SMBR (a) phylum level (b) genus level (c) Ammonia Oxidizing Bacteria and Nitrite Oxidizing Bacteria.

The genus-level distributions, abundances, and changes in the AOB and NOB reads during the different stages are shown in Figure 5c. Nitrosomonas was detected as the AOB, whereas Nitrolance and Nitrospira were the NOB. According to the ammonia valley, the relative abundance of AOB in the SMBR was only $0.1 \%$ in Stage I due to the control of the oxic phase. After combining with the $\mathrm{MC}$ process, the relative abundance of $\mathrm{AOB}$ was increased to $1.78 \%$, with a higher growth rate. The reason was that the MC pretreatment reduced the organic carbon in the influent, which was beneficial for the growth of autotrophic bacteria, such as $\mathrm{AOB}$ and NOB. Besides, the reasonable aeration time of the SMBR was conducive to the elimination of NOB.

A redundancy analysis (RDA) was conducted to reveal the species distributions in the samples along with controlling parameters at the genus level (Figure 6). Sludge samples from Stage I, Stage II, and Stage III were clustered in different groups (Figure S3). Sludge samples in Stage I had a positive correlation with the COD/TN ratio of the influent. Sludge samples on days 155, 163, and 171 deviated from the other samples, and positively correlated with the $\mathrm{NO}_{3}^{-}-\mathrm{N}$ concentration of the effluent. Distributions of AOB and NOB are described in Figure 6, which are negatively correlated with the COD/TN ratio and predominated in Stage II and Stage III. The abundance of AOB was enriched in Stage II and Stage III due to the removal of organic matter and SS with the introduction of the MC pre-treatment process. 


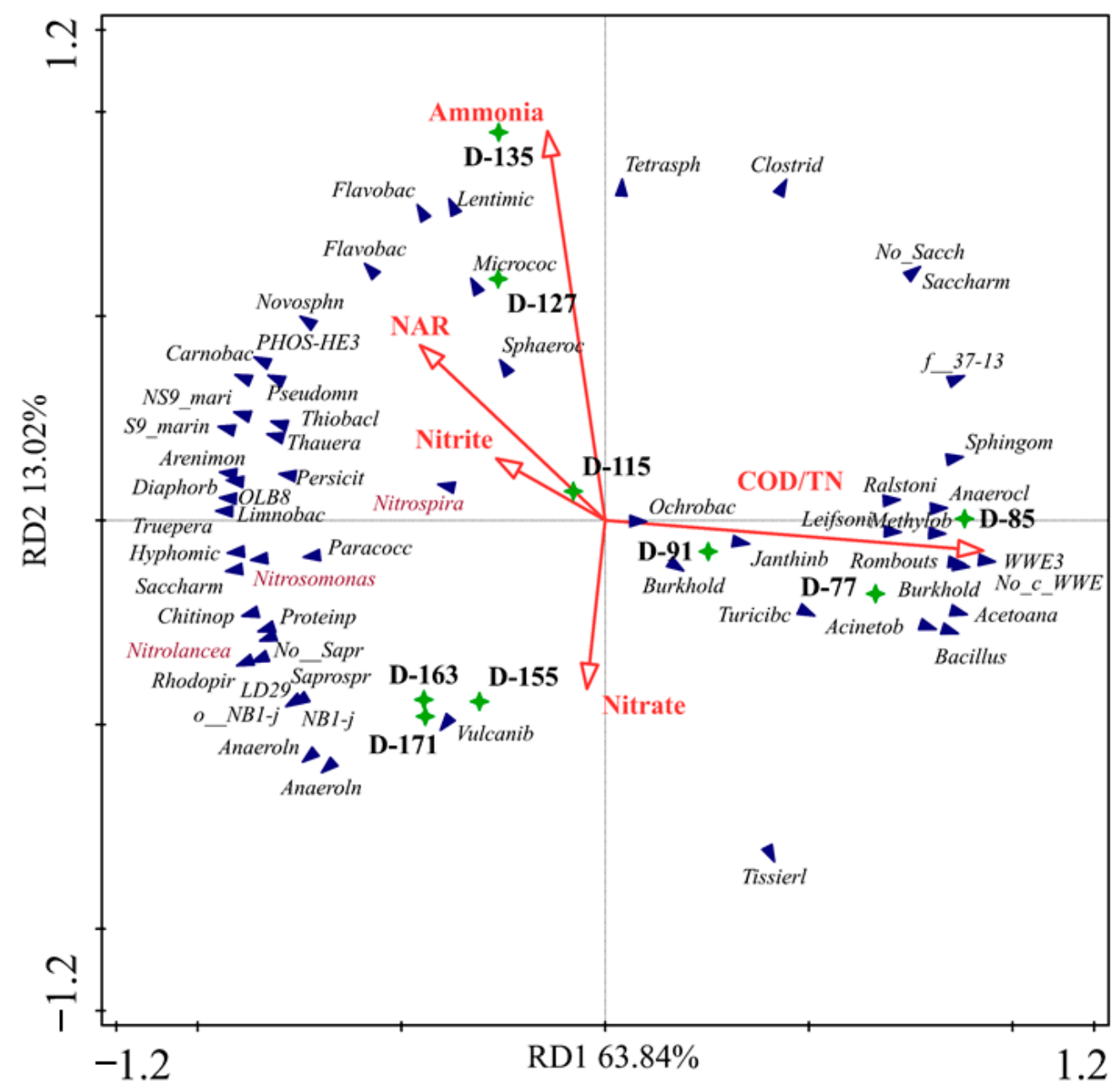

Figure 6. The redundancy analysis (RDA) of the parameters.

\section{Conclusions}

The short-cut combined MC-SMBR process was successfully developed to treat the swine wastewater, and its removal efficiencies were $99.0 \%, 97.6 \%, 96.0 \%$, and $69.1 \%$ for $\mathrm{NH}_{4}^{+}-\mathrm{N}, \mathrm{TN}, \mathrm{COD}$, and TP, respectively. The nitrogen removal loading of the SMBR increased (from 0.21 to $0.28 \mathrm{~kg} /\left(\mathrm{m}^{3} \cdot \mathrm{d}\right.$ )), and the HRT was shortened by $14 \%$ (from $5.0 \mathrm{~d}$ to $4.3 \mathrm{~d}$ ) with the introduction of the MC process. Besides, the relative abundance of AOB in the SMBR increased from $0.1 \%$ in Stage I to $1.78 \%$ in Stage III, which is beneficial for improving AOB activity in the SMBR due to the removal of SS and organic matter by the $\mathrm{MC}$ pre-treatment. Considering the economic, technical, and performance factors, the MC in Stage II with dosages of PAC, PAM, and magnetic seeds of $0.5 \mathrm{~g} / \mathrm{L}, 2 \mathrm{mg} / \mathrm{L}$, and $1 \mathrm{~g} / \mathrm{L}$, respectively, was more suitable for swine wastewater pre-treatment.

Supplementary Materials: The following are available online at https:/ / www.mdpi.com/2077-0 375/11/2/83/s1, Equation (S1): Calculation formula of activity of ammonia oxidation bacteria; Equation (S2): Calculation formula of activity of nitrite oxidation bacteria; Equation (S3): Calculation formula of free ammonia (FA); Table S1: Characteristics of influent swine wastewater at different stages; Table S2: Performance of magnetic coagulation pretreatment of swine wastewater at different stages; Table S3: Operating parameters and performance of the SMBR at different stages; Table S4: Performance comparison of the combined magnetic coagulation-SMBR process treating swine wastewater Figure S1: activity of AOB\&NOB in the SMBR at different stages; Figure S2: TMP and membrane flux in SMBR at different stages; Figure S3: Principle component analysis of the microbial community in the SMBR. 
Author Contributions: Conceptualization, Y.W. and Y.C.; methodology, Y.C.; validation, Q.S., D.Y. and L.Z.; formal analysis, Y.C.; investigation, M.C. and T.R.; writing—original draft preparation, Y.C.; writing-review and editing, Y.W.; supervision, Y.W. All authors have read and agreed to the published version of the manuscript.

Funding: This research was funded by the National Key Research and Development Program of China, grant number 2016YFD0501405 and the Key Research and Development Program of Jiangxi Province, grant number 20171ACG70018.

Institutional Review Board Statement: Not applicable.

Informed Consent Statement: Informed consent was obtained from all subjects involved in the study.

Data Availability Statement: Data is contained within the article or supplementary material.

Conflicts of Interest: The authors declare that they have no known competing financial interests or personal relationships that could have appeared to influence the work reported in this paper.

\section{References}

1. Ministry of Ecology and Environment of People's Republic of China. Bulletin of the Second National Census of Pollution Sources in China. Available online: http:/ / www.mee.gov.cn/xxgk2018/xxgk/xxgk01/202006/W020200610353985963290.pdf (accessed on 10 September 2020).

2. Yu, J.J.; Hu, H.C.; Wu, X.D.; Zhou, T.; Liu, Y.H.; Ruan, R.; Zheng, H.L. Coupling of biochar-mediated absorption and algal-bacterial system to enhance nutrients recovery from swine wastewater. Sci. Total Environ. 2020, 701, 134935. [CrossRef] [PubMed]

3. Cheng, H.H.; Narindri, B.; Chu, H.; Whang, L.M. Recent advancement on biological technologies and strategies for resource recovery from swine wastewater. Bioresour. Technol. 2020, 303, 122861. [CrossRef] [PubMed]

4. Hai, R.T.; He, Y.Q.; Wang, X.H.; Li, Y. Simultaneous removal of nitrogen and phosphorus from swine wastewater in a sequencing batch biofilm reactor. Chin. J. Chem. Eng. 2015, 23, 303-308. [CrossRef]

5. Lourinho, G.; Brito, P.S.D. Electrolytic Treatment of Swine Wastewater: Recent Progress and Challenges. Waste Biomass Valorization 2020, 1-24. [CrossRef]

6. Wang, X.; Yang, R.; Zhang, Z.; Wu, J.; Chen, S. Mass balance and bacterial characteristics in an in-situ full-scale swine wastewater treatment system occurring anammox process. Bioresour. Technol. 2019, 292, 122005. [CrossRef]

7. Nagarajan, D.; Kusmayadi, A.; Yen, H.-W.; Dong, C.-D.; Lee, D.-J.; Chang, J.-S. Current advances in biological swine wastewater treatment using microalgae-based processes. Bioresour. Technol. 2019, 289, 121718. [CrossRef]

8. Sandefur, H.N.; Asgharpour, M.; Mariott, J.; Gottberg, E.; Vaden, J.; Matlock, M.; Hestekin, J. Recovery of nutrients from swine wastewater using ultrafiltration: Applications for microalgae cultivation in photobioreactors. Ecol. Eng. 2016, 94, 75-81. [CrossRef]

9. Jiang, M.M.; Westerholm, M.; Qiao, W.; Wandera, S.M.; Dong, R.J. High rate anaerobic digestion of swine wastewater in an anaerobic membrane bioreactor. Energy 2020, 193, 677-687. [CrossRef]

10. Ding, X.; Zhao, J.; Chen, Y.; Hu, B.; Ma, B. Comparison of nitrogen and phosphorus removal performances for traditional and modified A $2 / O$ process. Chin. J. Environ. Eng. 2018, 12, 1480-1489.

11. He, L.-Y.; He, L.-K.; Liu, Y.-S.; Zhang, M.; Zhao, J.-L.; Zhang, Q.-Q.; Ying, G.-G. Microbial diversity and antibiotic resistome in swine farm environments. Sci. Total Environ. 2019, 685, 197-207. [CrossRef]

12. Kelly, P.T.; He, Z. Nutrients removal and recovery in bioelectrochemical systems: A review. Bioresour. Technol. 2014, 153, 351-360. [CrossRef] [PubMed]

13. Sui, Q.; Jiang, C.; Yu, D.; Chen, M.; Zhang, J.; Wang, Y.; Wei, Y. Performance of a sequencing-batch membrane bioreactor (SMBR) with an automatic control strategy treating high-strength swine wastewater. J. Hazard. Mater. 2018, 342, 210-219. [CrossRef] [PubMed]

14. Yang, D.; Deng, L.; Zheng, D.; Wang, L.; Liu, Y. Separation of swine wastewater into different concentration fractions and its contribution to combined anaerobic-aerobic process. J. Environ. Manag. 2016, 168, 87-93. [CrossRef] [PubMed]

15. Xu, G. Research on Pretreatment Technology of Diary Farm Wastewater; Yangzhou University: Yangzhou, China, 2019.

16. Zeng, Z.; Zheng, P.; Shi, C.; Zhang, M.; Shan, S. A challenge in anaerobic digestion of swine wastewater: Recalcitrance and enhanced-degradation of dietary fibres. Biodegradation 2019, 30, 389-400. [CrossRef] [PubMed]

17. Ritigala, T.; Demissie, H.; Chen, Y.; Zheng, J.; Zheng, L.; Zhu, J.; Fan, H.; Li, J.; Wang, D.; Weragoda, S.K.; et al. Optimized pretreatment of high strength food waste digestate by high content aluminum-nanocluster based magnetic coagulation. J. Environ. Sci. 2021, 104, 430-443.

18. Lv, M.; Zhang, Z.H.; Zeng, J.Y.; Liu, J.F.; Sun, M.C.; Yadav, R.S.; Feng, Y.J. Roles of magnetic particles in magnetic seeding coagulation-flocculation process for surface water treatment. Sep. Purif. Technol. 2019, 212, 337-343. [CrossRef]

19. Luo, G.; Zhang, C.; Zheng, L.; Wei, Y.; Yu, D. Optimization and evaluation of magnetic coagulation process pretreating swine manure biogas slurry. Chin. J. Environ. Eng. 2019, 13, 414-423.

20. Luo, L.; Nguyen, A.V. A review of principles and applications of magnetic flocculation to separate ultrafine magnetic particles. Sep. Purif. Technol. 2016, 172, 85-99. [CrossRef] 
21. Wang, S.; Cheng, F.; Guo, X.; Shen, S. Mechanism analysis of magnetic powder function in deep phosphorus removal by magnetic coagulation. Chin. J. Environ. Eng. 2019, 13, 302-309.

22. Zheng, L.; Jiao, Y.; Chen, M.; Wang, Z.; Zhang, H.; Zhenjun, W.; Huang, G.; Yu, W.; Wei, Y. The pollutants removal in municipal wastewater treatment by magnetic coagulation technology. Acta Sci. Circumstantiae 2020, 40, 2118-2127.

23. Wang, C.R.; Ren, X.; Li, W.X.; Hou, Z.F.; Ke, C.; Geng, Q. Magnetic Flocculation Technology for Copper and Zinc Ions Removal from the Tin Smelting Wastewater. Appl. Mech. Mater. 2013, 295-298, 1284-1288. [CrossRef]

24. Sui, Q.; Chen, Y.; Yu, D.; Wang, T.; Hai, Y.; Zhang, J.; Chen, M.; Wei, Y. Fates of intracellular and extracellular antibiotic resistance genes and microbial community structures in typical swine wastewater treatment processes. Environ. Int. 2018, 133, 105183. [CrossRef] [PubMed]

25. Wang, Y.; Wang, Y.; Wei, Y.; Chen, M. In-situ restoring nitrogen removal for the combined partial nitritation-anammox process deteriorated by nitrate build-up. Biochem. Eng. J. 2015, 98, 127-136. [CrossRef]

26. Gonzalez-Tineo, P.A.; Duran-Hinojosa, U.; Delgadillo-Mirquez, L.R.; Meza-Escalante, E.R.; Gortares-Moroyoqui, P.; UlloaMercado, R.G.; Serrano-Palacios, D. Performance improvement of an integrated anaerobic-aerobic hybrid reactor for the treatment of swine wastewater. J. Water Process Eng. 2020, 34, 101164. [CrossRef]

27. Lü, J.; Yuan, Z.; Li, W.; Wei, Y.; Fan, S. Experimental study of phosphorus removal from oil-bearing cleaning wastewater by coagulation sedimentation. Ind. Water Treat. 2019, 39, 37-41.

28. Oberson, A.; Tagmann, H.U.; Langmeier, M.; Dubois, D.; Mäder, P.; Frossard, E. Fresh and residual phosphorus uptake by ryegrass from soils with different fertilization histories. Plant Soil 2010, 334, 391-407. [CrossRef]

29. Oginni, O.; Yakaboylu, G.A.; Singh, K.; Sabolsky, E.M.; Unal-Tosun, G.; Jaisi, D.; Khanal, S.; Shah, A. Phosphorus adsorption behaviors of $\mathrm{MgO}$ modified biochars derived from waste woody biomass resources. J. Environ. Chem. Eng. 2020, 8, 103723. [CrossRef]

30. Kim, D.; Min, K.J.; Lee, K.; Yu, M.S.; Park, K.Y. Effects of pH, molar ratios and pre-treatment on phosphorus recovery through struvite crystallization from effluent of anaerobically digested swine wastewater. Environ. Eng. Res. 2017, 22, 12-18. [CrossRef]

31. Xiang, L.J. Application of magnetic coagulation process for slightly polluted river water treatment. Chin. J. Environ. Eng. 2014, 8, 2901-2905.

32. Kim, J.H.; Chen, M.; Kishida, N.; Sudo, R. Integrated real-time control strategy for nitrogen removal in swine wastewater treatment using sequencing batch reactors. Water Res. 2004, 38, 3340-3348. [CrossRef]

33. Han, Z.; Chen, S.; Lin, X.; Yu, H.; Duan, L.A.; Ye, Z.; Jia, Y.; Zhu, S.; Liu, D. Performance and membrane fouling of a step-fed submerged membrane sequencing batch reactor treating swine biogas digestion slurry. J. Environ. Sci. Health Part A 2017, 1-8. [CrossRef] [PubMed]

34. Yao, S.; Chen, L.P.; Guan, D.T.; Zhang, Z.G.; Tian, X.J.; Wang, A.M.; Wang, G.T.; Yao, Q.; Peng, D.; Li, J.Y. On-site nutrient recovery and removal from source-separated urine by phosphorus precipitation and short-cut nitrification-denitrification. Chemosphere 2017, 175, 210-218. [CrossRef] [PubMed]

35. Zheng, X.; Zhou, W.N.; Wan, R.; Luo, J.Y.; Su, Y.L.; Huang, H.N.; Chen, Y.G. Increasing municipal wastewater BNR by using the preferred carbon source derived from kitchen wastewater to enhance phosphorus uptake and short-cut nitrification-denitrification. Chem. Eng. J. 2018, 344, 556-564. [CrossRef]

36. Li, J.B.; Ye, W.; Wei, D.; Ngo, H.H.; Guo, W.S.; Qiao, Y.M.; Xu, W.Y.; Du, B.; Wei, Q. System performance and microbial community succession in a partial nitrification biofilm reactor in response to salinity stress. Bioresour. Technol. 2018, 270, 512-518. [CrossRef] [PubMed]

37. Wei, D.; Ngo, H.H.; Guo, W.S.; Xu, W.Y.; Du, B.; Wei, Q. Partial nitrification granular sludge reactor as a pretreatment for anaerobic ammonium oxidation (Anammox): Achievement, performance and microbial community. Bioresour. Technol. 2018, 269 , 25-31. [CrossRef] [PubMed]

38. Zhang, T.; Shao, M.F.; Ye, L. 454 Pyrosequencing reveals bacterial diversity of activated sludge from 14 sewage treatment plants. Isme J. 2012, 6, 1137-1147. [CrossRef] [PubMed]

39. Michael, D.; Franke-Whittle, I.H.; Heribert, I.; Yona, C.; Yitzhak, H.J.F.M.E. Molecular analysis of bacterial community succession during prolonged compost curing. J. FEMS Microbiol. Ecol. 2008, 65, 133-144. 